\title{
Intestinal electrical activity: a means of assessing viability
}

\author{
E. Q. Archampong \\ B.Sc., M.B., F.R.C.S. (Eng. \& Edin.) \\ Department of Surgery, \\ Ghana Medical School, \\ Accra, Ghana
}

\section{Summary}

Experiments on ten dogs confirm the impression that electromyographic activity is an important criterion of viability of the intestine subjected to vascular insults.

In all animals gangrene occurred only with complete loss of electrical activity; minimal activity $(0.3 \mathrm{mV})$ was compatible with recovery.

For acceptance in clinical practice it will be essential to prove by further experimental work that an electrically inactive bowel is indeed gangrenous.

\section{Introduction}

It is accepted practice to assess the activity and viability of the myocardium, the brain and skeletal muscle, respectively, with the aid of electrocardiography, electroencephalography and electromyography. Extension of this principle to the investigation of the smooth muscle of the intestine has been less enthusiastic although intestinal electromyography has been intensively studied in the past (Alvarez \& Mahoney, 1922; Bozler, 1938, 1939, 1942, 1945, 1949; Ambache, 1947; Milton \& Smith, 1956; Holaday, Volk \& Mandell, 1958; Bass, Code \& Lambert, 1961).

To Schamaun (1966) must be attributed the first scientific demonstration of the application of electromyography to assess viability of the bowel. Much, however, remains to be clarified in the practical use of this investigative procedure. The basis of this preliminary report is a study aimed at establishing electromyographic criteria of intestinal viability.

\section{Methods}

Electromyographic studies were made on ten dogs weighing between 9 and $30.2 \mathrm{~kg}$. Anaesthesia was with pentobarbitone, $35 \mathrm{mg} / \mathrm{kg}$ body weight, and maintained by additional doses of the drug. Three pairs of segments of intestine each $40 \mathrm{~cm}$ long in the jejunum, mid-ileum and terminal ileum, respectively, were delimited and their vascular pedicles dissected out, so that the segments were effectively isolated. The artery alone in one of a pair of segments was

\author{
StANISLAV REINIS \\ M.D., Ph.D. \\ Department of Physiology, \\ Ghana Medical School, \\ Accra, Ghana
}

dissected out and both artery and vein defined in the other.

For recording, fine silver chloride needles $(0.4 \mathrm{~mm})$ connected to insulated leads were employed. One needle was inserted into the intestinal wall subserosally and secured by means of a stitch; a second needle was fixed to the muscle of the abdominal wall. Recordings were made both on the oscilloscope (Tectronix 502A) and an adapted ECG machine (Cardioview). In the latter the intestinal pick-up needle was connected to the left leg lead and the abdominal electrode to the left arm lead.

The artery alone was cross-clamped for periods of 4-20 $\mathrm{hr}$ and both vein and artery for 4-24 hr. In two dogs intestinal obstruction was produced by tying off a loop of bowel in one segment. Monopolar electromyograms before, and at various stages during and after release of the clamp were obtained. Influences of temperature and $\mathrm{pH}$ were studied by bathing the bowel in physiological saline at temperatures between $40^{\circ}$ and $20^{\circ} \mathrm{C}$ and immersion in buffer-solution of $\mathrm{pH} 3$ to $\mathrm{pH} 9$.

\section{Results}

The characteristic basic electrical rhythm of Bass et al. (1961) was obtained and found to vary in frequency from $21 / \mathrm{min}$ at the upper jejunum to $8 / \mathrm{min}$ in the terminal ileum but at any site was constant. This is in agreement with the findings of Milton \& Smith (1956).

\section{Effects of vascular occlusion}

Application of the clamp to the artery resulted in blanching and shrinkage of the segment, maintained until inspection 4 or $20 \mathrm{hr}$ later. Electromyographic activity showed decrease in frequency and amplitude (Table 1) but never really disappeared (Fig. 1). After release of the clamps all segments recovered their colour and electrical activity was almost completely restored.

Occlusion of artery and vein produced rapid engorgement and darkening of both bowel and mesentery. There was some variation between the 
TABLE 1. Effect on electromyographic activity of cross-clamping the artery in segments of dog intestine

\begin{tabular}{|c|c|c|c|c|}
\hline Segment & $\begin{array}{l}\text { Period of } \\
\text { occlusion } \\
\quad \text { (hr) }\end{array}$ & $\begin{array}{l}\text { Frequency of activity } \\
\text { before clamping } \\
\text { (per min) }\end{array}$ & $\begin{array}{l}\text { Frequency of activity } \\
\text { after clamping } \\
\text { (per min) }\end{array}$ & $\begin{array}{l}\text { Frequency of activity } \\
\text { after release of } \\
\text { clamp (per min) }\end{array}$ \\
\hline 1 & 4 & $\begin{array}{c}17 \cdot 4-18 \cdot 5(20) \text { Mean } 17 \cdot 9 \\
2 \cdot 6 \mathrm{mV}\end{array}$ & $\begin{array}{c}13 \cdot 8-14 \cdot 4(25) \text { Mean } 14 \cdot 1 \\
1.6 \mathrm{mV}\end{array}$ & $\begin{array}{c}13 \cdot 6-14 \cdot 4(10) \text { Mean } 14 \cdot 0 \\
2 \cdot 3 \mathrm{mV}\end{array}$ \\
\hline 2 & 12 & $\begin{array}{c}17 \cdot 6-18 \cdot 4(20) \text { Mean } 18 \cdot 0 \\
2.6 \mathrm{mV}\end{array}$ & $\begin{array}{c}11 \cdot 8-12 \cdot 6(15) \text { Mean } 12 \cdot 2 \\
1 \cdot 2 \mathrm{mV}\end{array}$ & $\begin{array}{c}11 \cdot 0-12 \cdot 5(15) \underset{\mathrm{MV}}{\mathrm{M}} 11 \cdot 7 \\
1.6 \mathrm{mV}\end{array}$ \\
\hline 3 & 20 & $\begin{array}{c}17 \cdot 4-18 \cdot 6(15) \text { Mean } 18 \cdot 0 \\
2 \cdot 5 \mathrm{mV}\end{array}$ & $\begin{array}{c}8 \cdot 5-9 \cdot 4(10) \text { Mean } 8.9 \\
1.0 \mathrm{mV}\end{array}$ & $\begin{array}{c}6 \cdot 5-8 \cdot 8(10) \quad \text { Mean } 7 \cdot 6 \\
1 \cdot 2 \mathrm{mV}\end{array}$ \\
\hline
\end{tabular}

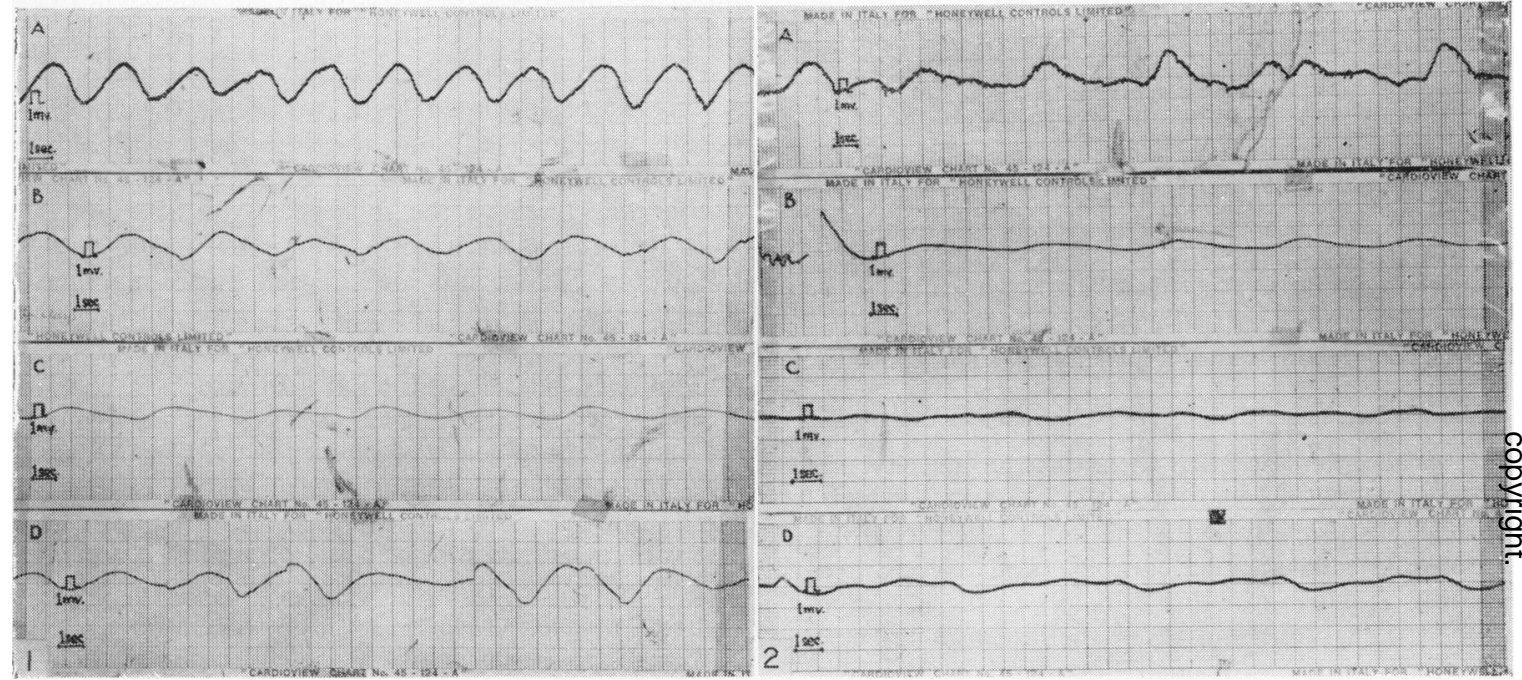

FIG. 1. Effect of cross-clamping of artery alone in segments of dog ileum $30 \mathrm{~cm}$ from duodeno-jejunal flexure. A, Before clamping; B, after clamping for $4 \mathrm{hr}$; C, after clamping for $12 \mathrm{hr}$; D, $30 \mathrm{~min}$ after release of the clamp.

Fig. 2. Effect of cross-clamping of artery and vein in segments of dog ileum $30 \mathrm{~cm}$ from duodeno-jejunal flexure. A-D as in Fig. 1.

TABLE 2. Effect on electromyographic activity of cross-clamping both artery and vein in segments of dog intestine

\begin{tabular}{|c|c|c|c|c|}
\hline Segment & $\begin{array}{l}\text { Period of } \\
\text { occlusion } \\
\quad \text { (hr) }\end{array}$ & $\begin{array}{l}\text { Frequency of activity } \\
\text { before clamping } \\
\text { (per min) }\end{array}$ & $\begin{array}{l}\text { Frequency of activity } \\
\text { after clamping } \\
\text { (per min) }\end{array}$ & $\begin{array}{l}\text { Activity } \frac{1}{2} \text { hr } \\
\text { after release of } \\
\text { clamp (per min) }\end{array}$ \\
\hline 1 & 4 & $\begin{array}{c}17 \cdot 6-18 \cdot 6(20) \underset{\mathrm{mV}}{\text { Mean }} 18 \cdot 1 \\
\end{array}$ & $\begin{array}{c}11 \cdot 0-11 \cdot 4(15) \text { Mean } 11.2 \\
0.6 \mathrm{mV}\end{array}$ & $\begin{array}{c}10 \cdot 2-11 \cdot 0(15) \text { Mean } 10 \cdot 6 \\
1.0 \mathrm{mV}\end{array}$ \\
\hline 2 & 12 & $\begin{array}{c}18 \cdot 0-18 \cdot 2(15) \mathrm{Mean} \\
2 \cdot 5 \mathrm{mV}\end{array}$ & - & $\begin{array}{c}7 \cdot 5-8 \cdot 0(20) \underset{\mathrm{mV}}{\text { Mean }} 7 \cdot 7 \\
1.0 \mathrm{~m}\end{array}$ \\
\hline 3 & 24 & $\begin{array}{c}17 \cdot 8-18.0(15) \text { Mean } 17.9 \\
2.6 \mathrm{mV}\end{array}$ & - & - \\
\hline $\begin{array}{c}\text { Intestinal } \\
\text { obstruction }\end{array}$ & 50 & $\begin{array}{c}16 \cdot 0-16 \cdot 2(15) \mathrm{Mean} 16 \cdot 1 \\
2 \cdot 4 \mathrm{mV}\end{array}$ & $\begin{array}{c}4 \cdot 0-4 \cdot 5(10) \text { Mean } 4 \cdot 2 \\
0 \cdot 3 \mathrm{mV}\end{array}$ & $\begin{array}{c}10 \cdot 2-10 \cdot 5(20) \text { Mean } 10 \cdot 3 \\
0.6 \mathrm{mV}\end{array}$ \\
\hline $\begin{array}{l}\text { Intestinal } \\
\text { obstruction }\end{array}$ & 48 & $\begin{array}{c}16 \cdot 2-16 \cdot 6(10) \text { Mean } 16 \cdot 3 \\
2 \cdot 4 \mathrm{mV}\end{array}$ & - & - \\
\hline
\end{tabular}


TABLE 3. Effect of temperature on electromyographic activity

\begin{tabular}{|c|c|c|}
\hline Temperature $\left({ }^{\circ} \mathrm{C}\right)$ & Upper ileum & Lower ileum \\
\hline $40^{\circ}$ & $\begin{array}{c}16 \cdot 0-15 \cdot 5(10) \text { Mean } 15 \cdot 7 \\
2 \cdot 8 \mathrm{mV}\end{array}$ & $\begin{array}{c}12.5-13.0(12) \text { Mean } 12.7 \\
2.0 \mathrm{mV}\end{array}$ \\
\hline $33^{\circ}$ & $\begin{array}{c}12 \cdot 0-13 \cdot 5(15) \mathrm{Mean} 12 \cdot 7 \\
2 \cdot 0 \mathrm{mV}\end{array}$ & $\begin{array}{c}8 \cdot 4-9 \cdot 5(10) \text { Mean } 8 \cdot 9 \\
1 \cdot 8 \mathrm{mV}\end{array}$ \\
\hline $20^{\circ}$ & $\begin{array}{c}9 \cdot 0-10 \cdot 2(15) \text { Mean } 9.6 \\
1.5 \mathrm{mV}\end{array}$ & $\begin{array}{c}6.0-7.5(15) \text { Mean } 6.7 \\
1.5 \mathrm{mV}\end{array}$ \\
\hline
\end{tabular}

TABLE 4. Effect of $\mathrm{pH}$ on electromyographic activity

\begin{tabular}{|c|c|c|c|}
\hline \multirow[b]{2}{*}{ pH } & \multicolumn{2}{|c|}{ Dog } & \multirow{2}{*}{$\begin{array}{l}\text { Guinea-pig: } \\
\text { activity of ileum } \\
\text { (per min) }\end{array}$} \\
\hline & $\begin{array}{l}\text { Activity of upper } \\
\text { ileum (per min) }\end{array}$ & $\begin{array}{l}\text { Activity of lower } \\
\text { ileum (per min) }\end{array}$ & \\
\hline 7 & $\begin{array}{c}19 \cdot 5-20(15) \underset{3 \cdot 0}{\mathrm{mV}} \\
\text { Mean } 19 \cdot 7\end{array}$ & $\begin{array}{c}8 \cdot 5-9 \cdot 8(15) \text { Mean } 9 \cdot 1 \\
2.0 \mathrm{mV}\end{array}$ & $\begin{array}{c}8 \cdot 0-8 \cdot 6(20) \text { Mean } 8 \cdot 3 \\
1.2 \mathrm{mV}\end{array}$ \\
\hline 5 & $\underset{1.5 \mathrm{mV}}{11 \cdot 5-12 \cdot 5(20) \underset{M e a n}{12} \cdot 0}$ & $\begin{array}{c}8 \cdot 0-9 \cdot 0(12) \text { Mean } 8 \cdot 5 \\
1 \mathrm{mV}\end{array}$ & $\begin{array}{c}7 \cdot 0-7 \cdot 5(15) \text { Mean } 7 \cdot 3 \\
1.0 \mathrm{mV}\end{array}$ \\
\hline 3 & $\begin{array}{c}8 \cdot 0-9 \cdot 5(15) \text { Mean } 8 \cdot 7 \\
1 \mathrm{mV}\end{array}$ & $\begin{array}{c}6 \cdot 1-7 \cdot 3(15) \underset{0.5 \mathrm{mV}}{\text { Mean }} 6 \cdot 7 \\
\text {. }\end{array}$ & $\begin{array}{c}6.0-6 \cdot 5(15) \text { Mean } 6.3 \\
0.25 \mathrm{mV}\end{array}$ \\
\hline 9 & $20 \cdot 0-20 \cdot 5(15)$ Mean $20 \cdot 2$ & 8.6-9.4(12) Mean 9.0 & $\begin{array}{c}8 \cdot 2-8 \cdot 4(15) \text { Mean } 8 \cdot 3 \\
1.0 \mathrm{mV}\end{array}$ \\
\hline
\end{tabular}

segments in the speed of deterioration of electromyographic activity. In one dog low-grade activity was demonstrable after $24 \mathrm{hr}$ of occlusion and the bowel recovered on release of the clamp but in all the other segments occlusion for $12 \mathrm{hr}$ or more produced irreversible loss of electrical activity with gangrene (Fig. 2 and Table 2). In the two dogs with induced intestinal obstruction, the bowel retained a low grade activity $(0.3 \mathrm{mV})$ with complete recovery on relief of obstruction; the other developed gangrene and died.

The effects of temperature and $\mathrm{pH}$ are depicted in Tables 3 and 4. Raising the temperature also quickened return of electrical activity after vascular occlusion.

\section{Discussion}

The occlusion experiments indicate that small bowel electromyographic activity is particularly sensitive to anoxia. This is not surprising since electrical changes across the cell membrane reflecting ionic exchanges are dependent on an active force provided by cellular metabolism. This confirms Schamaun's (1967) findings.

It is evident further that reduction of activity to very low amplitude $(0.3 \mathrm{mV})$ is compatible with complete recovery. No reproducible patterns of altered activity were noted. In the animals studied infarction was noticed only in complete loss of electromyographic activity. Temperature or $\mathrm{pH}$ made no difference to the activity in these cases.

Work is in progress to establish precise quantitative criteria of viability by correlation with histology as well as animal survival. The procedure would find ready clinical application in the investigation of strangulated bowel, mesenteric thrombosis and embolism and trauma. However, for acceptance in clinical practice it would be essential to prove that a section of bowel found to show electrical activity below the accepted criteria is gangrenous. This calls for controlled experiments involving resection and preservation of bowel of critical electrical activity.

\section{References}

Alvarez, W.C. \& MaHONEY, L.J. (1922) Action currents in stomach and intestine. Amer. J. Physiol. 58, 476.

AMBACHE, N. (1947) Electrical activity of isolated mammalian intestine. J. Physiol. (Lond.), 106, 139.

BASS, P., CODE, C.F. \& LAMBERT, E.H. (1961) Motor and electric activity of the duodenum. Amer. J. Physiol. 201, 287.

BOzLER, E. (1938) Action potentials of visceral smooth muscle. Amer. J. Physiol. 124, 502.

Bozler, E. (1939) Electrophysiological studies on motility of gastro-intestinal tract. Amer. J. Physiol. 127, 301.

BOzLER, E. (1942) Action potentials accompanying conducted responses in visceral smooth muscle. Amer. J. Physiol. 136, 553.

Bozler, E. (1945) Action potentials of stomach. Amer. J. Physiol. 144, 693. 
Bozler, E. (1949) Reflex peristalsis of intestine. Amer. J. Physiol. 157, 338.

Holaday, D.A., Volk, H. \& Mandell, J. (1958) Electrical activity of the small intestine with special reference to the origin of rhythmicity. Amer. J. Physiol. 195, 505.

Milton, G.W. \& Sмiтh, A.W.M. (1956) Pace making area of the duodenum. J. Physiol. (Lond.), 132, 100.
Schamaun (1966) Experimentalle Elektromyographische Untersuchungen zur Pathophysiologie der Dunndarmmotorik bei Chirurgischen Krankheitsbildern. Z. ges. exp. Med. 141, 89.

Schamaun, M. (1967) Electromyography to determine viability of injured small bowel segments: an experimental study with preliminary clinical observation. Surgery, 62, 899. 